\title{
Analysis of regional droughts, magnitudes and comparison over Ballari district
}

HANUMANTHAPPA RAMDURG, G.V. SRINIVASA REDDY, D. KRISHNAMURTHY, B. MAHESHWARA BABU AND M. NEMICHANDRAPPA

Article Chronicle :

Received :

18.09.2015;

Revised :

01.11.2015;

Accepted :

15.11.2015

Key Words :

Droughts,

IMD criteria,

SPI criteria
ABSTRACT : Drought generally initiates with the deficit of monsoon rains leading to meteorological drought and if prolonged, affects other sectors dependent on the water for its sustenance resulting in agricultural and hydrological droughts. The present study was conducted to analyse and compare meteorological drought occurrence over various stations of Ballari district, Karnataka. The rainfall data of 35 years (1978-2012) was considered for the present study. The various magnitudes of droughts (mild, moderate, severe and extreme) were analysed and compared by IMD and SPI criteria's. The drought frequency of one drought year was observed for every one and half year to two years.

HOW TO CITE THIS ARTICLE : Ramdurg, Hanumanthappa, Reddy, G.V. Srinivasa, Krishnamurthy, D., Babu, B. Maheshwara and Nemichandrappa, M. (2015). Analysis of regional droughts, magnitudes and comparison over Ballari district. Asian J. Environ. Sci.,10(2): 156-160.
Author for correspondence :

G.V. SRINIVASA

REDDY

Department of Soil and Water Engineering,

College of Agricultural

Engineering, University of Agricultural Sciences, RAICHUR (KARNATAKA) INDIA

Email: gvsreddymtech@ rediffmail.com

See end of the article for

Coopted authors' 